\title{
THE IMPROVEMENT OF GENERATION Z FINANCIAL WELL-BEING IN PEKANBARU
}

\author{
Nicholas Renaldo $^{1 *}$, Sudarno Sudarno ${ }^{2}$, Marice Boru Hutahuruk ${ }^{3}$ \\ ${ }^{1,2}$ Institut Bisnis dan Teknologi Pelita Indonesia, ${ }^{3}$ STIE Prakarti Mulya, Indonesia \\ *Corresponding author; Email: ${ }^{1}$ nicholasrenaldo@ @ecturer.pelitaindonesia.ac.id, ${ }^{2}$ sudarno@lecturer.pelitaindonesia.ac.id, \\ 33rctalenta@yahoo.com
}

\begin{abstract}
The current economic condition of generation $\mathrm{Z}$ was pretty unexpected. It might trigger problems personally or even their families. This study aimed to reveal the factors influencing the financial well-being and altering personality problems of generation $Z$. There were more than 800,000 peoples in population and the number of the sample was 239 peoples using a combination of purposive and convenience sampling methods. The data was then analyzed using multiple linear regression. The researchers used primary data by distributing questionnaires based on a Likert Scale. All classic assumptions met the criteria and testing produced financial self-efficacy, financial attitude, financial knowledge, financial behavior, and had a significant positive effect on financial well-being. However, locus of control had no significant effect on financial well-being. Generation Z must increase their independence and confidence to achieve what they want. It would be good to have financial atitude and investment behavior along with financial knowledge. They must also believe that only theirself can provide personal well-being. Generation $\mathrm{Z}$ needed character education, more mature, and independent thinking models to deal with economic problems.
\end{abstract}

Keywords: Financial well-being, financial behavior, financial self-efficacy, financial knowledge, financial attitude.

\section{Introduction}

The economy is the dominant factor triggering people to think about living standards for the long term. Financial management skills are a crucial part of every stage of life (Sabri \& Zakaria, 2015). Generation Z (1995-2012) is a group facing a big challenge in making financial decisions because they tend to have low incomes and few assets; this process is their maturity process.

Technology continues to develop and affect everyone. Industry 5.0 is one indicator. Generation $\mathrm{Z}$ will certainly go with this flow and influence its economic factors. It is the impact of their lifestyle who like to gather with friends, shop online, vacation, or enjoy year-end leave. To fulfill these things, they certainly require a large fee.

It is serious since it may worsen the level of economy and lifestyle, which will also induce wellbeing. Based on a survey of generation Z, most of them work while in college and they tend to be mediocre in responding to their financial well-being. Those who already have work experience should better understand the financial situation and the future. The pre-survey shows $32 \%$ of generation $\mathrm{Z}$ are not worried too much about financial situations.
Indonesia's economy grows by $5 \%$, which has the opportunity to increase the positive impact of raising everyone's income. However, some people cannot manage their finances despite having high incomes. They will experience problems such as being unable to pay their bills on time, inferiority, and missing retirement plans. It makes their economic capacity drop to the lower middle level.

The most essential factor is creativity and skills to manage money as wisely as possible, to manage the budget, savings, and investment by maintaining their economic goals. But, some young people are lack of knowledge about finances so it worsens their financial implementation (Susan, 2018).

Generation $\mathrm{Z}$ seems so realistic and competitive. The way they deal with life is different compared to the generation of baby boomers (1946-1960), X (19611980), and Y or Millennial (1981-1944), who prefer safety zones based on their experience.

Serido, Shim, and Tang (2013) said financial selfefficacy has a positive and significant effect on financial well-being. Sabri and Zakaria (2015) in a study of behavior effect on financial well-being, found a significant positive effect. However, the conclusion is contrary to the research study of Abdullah, Sabri, and Arif (2019), which explicated positive and insignificant 
consequences. Falahati and Sabri (2015) proved that financial knowledge had a positive and significant effect on financial well-being. Research on the locus of control by Mokhtar and Rahim (2016) presented a significantpositive effect on financial well-being but it contradicts a study of Mokhtar and Rahim (2017). When examining financial behavior, Mokhtar and Husniyah (2017) concluded there was a significant and positive impact on financial well-being.

Theory of planned behavior (TPB) deals with rational actions and the assumption of human's behavior based on logic. They also reflect information and, directly or indirectly, calculate the impact of their actions. According to the theory of rational action, an individual will act if he considers it positive and thinks other people will do so (Arifin, 2017).

Generation $\mathrm{Z}$ who have worked basically has mature thoughts to manage their finances. This low level of welfare will disrupt their lives and should be dealt with immediately.

Based on the explanation above, research, and theoretical gaps, it is necessary to discuss more deeply about how to improve well-being of generation $\mathrm{Z}$ in Pekanbaru. The problems in this study include the factors influencing financial well-being in generation $\mathrm{Z}$ in Pekanbaru City.

\section{Financial Well-Being}

Financial well-being refers to the health of financial status, happiness, and peace of mind based on subjective judgment. Satisfaction with financial conditions is often considered as a sign to measure the financial situation (Sabri, Paim, Falahati, \& Masud, 2013).

Financial well-being serves as a determinant of life quality. For example, when an economic recession strikes and causes economic problems, every victim will certainly be worried and thinking about health, income, debt, and career. That concern affects mental health, physical, self-confidence, and work performances. In addition, it generally triggers employees to work late and disrupt their concentration (Sabri \& Zakaria, 2015).

\section{Financial Behavior}

Financial behavior is closely associated with financial management and is liable for managing personal finances. This is a union of cash flow management, credit management, and investment. Financial management focuses on effectiveness such as determining the budget and debt value. The control of money and savings expenditures is generally a benchmark of judgment.
Furthermore, this is also related to the way individuals manage and use financial resources. These measures include (1) expenses, (2) bill payments, (3) financial planning, (4) money for personal and family, and (5) savings (Arifin, 2018).

There are three determinants of theory of planned behavior, namely (1) behavioral beliefs, the results obtained, and evaluation of results, (2) normative beliefs, to achieve normative expectations shared with others, and (3) belief control, namely the existence of things supporting or hindering the behavior to emerge, and how strong the support or resistance (Arifin, 2018).

Rational behavior theory affirms when an individual feels an action will generate a positive thing for him, and then he will take it, or because others want to do it. Individual actions are influenced by two basic factors, attitudes originating from behavioral beliefs and subjective norms from normative beliefs (Arifin, 2017).

Some literature explains financial behavior and management can change the financial situation. Personal financial practices such as cash management, credit management, budgeting, financial planning, and general fund management greatly have (Sabri et al., 2013).

\section{Locus of Control}

It underlines the problem of one's thinking in controlling situations that affect him. This factor holds internal and external dimensions. Those who have an internal locus of control are always motivated by tenacity, while external locus of control entices individuals to think that aspects outside themselves, such as luck, opportunity, and destiny influence their lives (Mien \& Thao, 2015).

Locus of control can be interpreted as a person's perspective on an event whether he can or cannot control the events that occur to him. Locus of control consists of two constructs, namely internal and external, where if someone believes that what happens is always within his control and always takes a responsible role in every decision including internal locus of control, while someone who believes that events in his life are beyond its control is included in the external locus of control (Fitra, Rasyid, \& Susanti, 2018).

Locus of control is also a psychological variable with certain tendencies. Every individual has two types of tendencies: internal and external. People with an internal locus of control have better financial behavior than those with an external locus of control (Arifin, 2017). 


\section{Financial or Money Attitude}

Individuals' perspectives on the use of money ascertain their personality and management style. The tendency of their attitudes applies subjectively to act on gains or losses (Susan, 2018).

In the materialist world, money is not only a medium of exchange but also a device for achieving happiness and prosperity. Money itself has iconic values, such as: status, respect, freedom, and luxury. Materialists are commonly obsessed with money often feeling satisfied with their financial condition because they can realize their ideals. It means well-being of individuals depends on their life aspirations (Sabri \& Zakaria, 2015).

Financial attitude is a key factor in arranging financial success or failure. It also possesses psychological tendencies, which generally appear with a like or dislike attitude. Individuals will expose their expressions and decide to agree or reject a matter. It shows the level of intelligence of individuals in managing their finances. When they have a lot of money, their awareness and responsibilities also increase, and positively affect financial behavior (Arifin, 2018).

Financial attitude can also mean a person's mindset, opinion, and judgment about finance. There are at least three interdependent variables, based on the theory of social learning, namely behavior, environment, and events affecting perception and action. The event can be in the form of financial attitudes and good management behavior starting from the application of good and reasonable financial attitudes (Ameliawati \& Setiyani, 2018).

\section{Financial Knowledge}

There are two main aspects of the financial knowledge environment. This is relevant to the ability of respondents to apply general financial knowledge or special finance system as an equation of financial knowledge. to measure it, first, at least four aspects are needed, such as personal financial knowledge, general financial knowledge, investment, financial planning, and taxation. The scale of knowledge itself includes skills, information related to deposits and debits, insurance and investment projects, as well as financial information. The second is through the assessment of one's own knowledge. This principle is useful as an evaluation instrument (Susan, 2018).

Financial behavior requires financial knowledge. It may trigger the formation of good ideas that are useful in society. This literacy includes banking, savings, insurance, credit, taxes, and investment. Each individual has financial knowledge depending on their knowledge capacity and can be guided by an understanding of (1) interest rates, financial costs and credit, (2) credit rates and credit data, (3) financial management, (4) investment, and (5) credit report (Arifin, 2018).

The term financial knowledge is defined as sufficient knowledge about facts about personal finances (Mien \& Thao, 2015). Financial knowledge is the ability to understand, analyze, and manage finances. The intention is to create the best financial decisions and avoid financial problems. A person's financial knowledge requires developing financial skills and learning to use financial tools, such as preparing a budget, investment, and insurance plan. This knowledge can be from schools, seminars, training, and non-formal education.

\section{Financial Self-Efficacy}

Self-efficacy is an individual's belief with his ability to set a series of actions to achieve ambitions. The term also denotes someone's belief in changing financial behavior for the better. It is a vital component in Bandura's social cognitive theory that emphasizes the matter of one's confidence in completing his responsibility. This ability can help individuals to define achievement because they view difficult tasks as a challenge. They have a strong desire and commitment to success. For this reason, financial independence benefits to act and change financial behavior (Herawati, Candiasa, Yadnyana, \& Suharsono, 2018).

Perceived control and self-efficacy related to the two constructs are conceptually different. Self-efficacy is proportional to personal ability, whereas control of behavior is similar to the locus of control; causal beliefs about contingencies resulting from actions. Self-efficacy influences the process of facing challenges, how much force expended, how long to survive in facing obstacles and failures, and an indication that failure motivates or discourages the spirit. Hence, one's ability in financial behavior contributes to individual performance (Serido, Shim, \& Tang, 2013).

According to Faique et al. (2017), individuals with high self-efficacy are more likely to try some projects to develop their positive attitude. Conversely, if individuals have low self-efficacy, they tend to develop negative attitudes towards these actions.

\section{Hypothesis}

The hypotheses in this study are as follows: 
$H_{l}$ : Financial self-efficacy has a significant positive influence on financial well-being.

$\mathrm{H}_{2}$ : Financial attitude has a significant positive influence on financial well-being.

$H_{3}$ : Financial knowledge has a significant positive influence on financial well-being.

$H_{4}$ : Financial behavior has a significant positive influence on financial well-being.

$H_{5}$ : Locus of control has a significant positive influence on financial well-being.

\section{Research Framework}

To explain the impact of variables, the research framework is as follows:

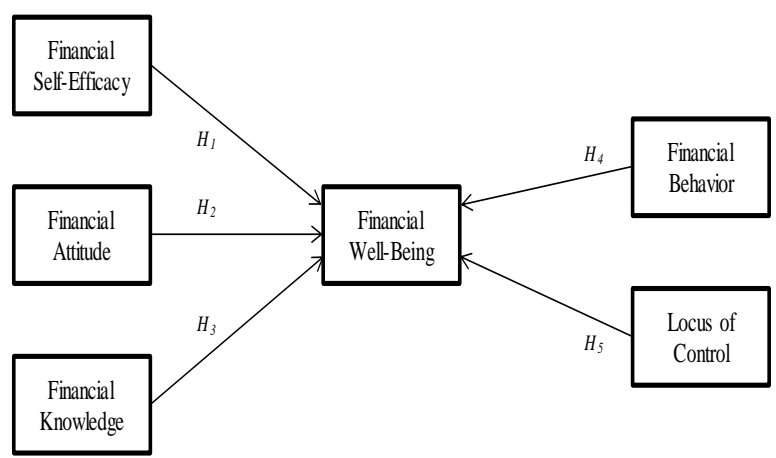

Figure 1. The conceptual research framework

\section{Research Methods}

This research study is descriptive with a quantitative approach using survey methods. Surveys are systems for gathering information from or about people to describe, compare, or explain their knowledge, attitudes, and behavior (Sekaran \& Bougie, 2016).

The researchers used a survey, questionnaires, and Likert scale methods to determine data and samples. The population was more than 800,000 peoples (generation Z of 18-25 years). According to (Bujang, Sa'at, \& Sidik, 2017), the minimum number of samples for the six variables tested using multiple regression analysis was 130. From 263 questionnaires, researchers only took 239 samples using purposive sampling and convenience sampling methods. Questionnaire recipient respondents are people in Pekanbaru City, which includes generation $\mathrm{Z}$ and at least graduate from high school or equivalent.

Indicators of each variable must be elaborated to find out the indicators forming latent variables. Indicators of each variable are listed in Table 1.
Table 1

\section{Research Variable Indicators}

\begin{tabular}{|c|c|c|}
\hline Attribute & Indicator & References \\
\hline & Financial Attitude & \\
\hline FA1 & $\begin{array}{l}\text { I compare credit options before } \\
\text { applying for installment }\end{array}$ & $\begin{array}{l}\text { (Potrich, Vieira, \& } \\
\text { Kirch, 2015) }\end{array}$ \\
\hline FA2 & I invest regularly & \\
\hline FA3 & $\begin{array}{l}\text { I am responsible for my financial well- } \\
\text { being }\end{array}$ & (Susan, 2018) \\
\hline FA4 & $\begin{array}{l}\text { I asked if I could get the same item at a } \\
\text { lower price after buying }\end{array}$ & $\begin{array}{l}\text { (Ali, Rahman, \& } \\
\text { Bakar, 2013) }\end{array}$ \\
\hline FA5 & I imagine how to manage money well & \\
\hline & Financial Behavior & \\
\hline FB1 & I have a reserve fund & (Potrich et al., 2015) \\
\hline FB2 & $\begin{array}{l}\text { I analyze finances before making a } \\
\text { large purchase }\end{array}$ & \\
\hline FB3 & $\begin{array}{l}\text { I save money every month for future } \\
\text { needs }\end{array}$ & $\begin{array}{l}\text { (Potrich, Vieira, \& } \\
\text { Mendes-Da-Silva, } \\
\text { 2016) }\end{array}$ \\
\hline FB4 & I make a plan to achieve financial goals & (Susan, 2018) \\
\hline FB5 & I buy bonds, stocks or mutual funds & $\begin{array}{l}\text { (Mien \& } \\
\text { Thao, 2015) }\end{array}$ \\
\hline
\end{tabular}

Financial Knowledge

FK1 I understand interest rates, financial (Susan, 2018) costs, and credit terms

FK2 I understand investment returns and risks

FK3 I understand how to minimize risk in investments

FK4 Purchasing power decreases when inflation increases

FK5 I understand financial concepts such as (Kumar, Watung, money management, investment, and Eunike, budgeting

\& Luinata, 2017)

Internal Locus of Control

IL1 Saving and investing carefully is a key (Pinjisakikool, 2017) factor for getting rich

IL2 I get rich or not depends largely on my ability

IL3 When I get what I want, it's usually because I work hard

IL4 My life is depending on my actions

IL5 Being rich has nothing to do with luck

Financial Well-Being

FW1 I have a healthy financial condition

FW2 I am comfortable dealing with the financial situation

FW3 I am confident in controlling personal finances

FW4 I am satisfied with my overall financial situation

FW5 I deserve an emergency benefit

Financial Self-Efficacy

FS1 I can always overcome difficult (Lown, 2011) problems if I try hard

(Delafrooz \& Paim, 2011a, 2011b)

FS2 I stick to spending plans when unexpected expenses arise

FS3 I am challenged to make progress towards financial goals

FS4 I can find a way to get what I want (Schwarzer \& Jerusalem, 1995)

FS5 I feel confident in my ability to manage (Serido, Shim, my finances

\& Tang, 2013) 


\section{Data Analysis Technique}

\section{Descriptive Analysis}

This descriptive analysis explains the discussion of respondent characteristics related to respondent responses. Analysis of respondents' characteristics consisted of age, sex, marital status, employment, home ownership status, ethnicity, religion, income, fund placement, and primary and secondary financial socialization agents. The subsequent analysis used a model and analysis of respondent responses containing a discussion of respondent responses related to the characteristics of respondents using the ANOVA method.

\section{Questionnaire Eligibility Test}

The researcher first tested the primary data before the influence test. Validity shows the data quality covering the actual area of investigation. One important item in validity is loading factor above 0.40 , which is the minimum value suggested in the study. The second test was reliability involving the extent to which the measurement of a phenomenon provided stable and consistent results. The Cronbach's Alpha coefficient is the most commonly used measure of consistency. Reliability is recommended equally to or above 0.60 (Taherdoost, 2016).

\section{Classical Assumption of Multiple Linear Regressions}

There are some assumptions of multiple linear regression (Lind, Marchal, \& Wathen, 2017), namely linear, homoscedasticity, distribution of residuals following a normal distribution, no multicollinearity, and no autocorrelation. All tests in this analysis applied Microsoft Excel and SPSS applications.

\section{Analysis of Multiple Linear Regression Equations}

Multiple linear regression has ordinarily been utilized as a statistical tool to predict the dependent variables based on a set of predictors (Bujang et al., 2017).

\section{Hypothesis Test}

Hypothesis testing used the SPSS program. If the value of $\operatorname{Sig}<\alpha$, there is the independent variables significantly influence the dependent variable.

\section{Results and Discussion}

\section{Descriptive Statistics}

The age of most respondents was 20 years (35.9\%). The number of male respondents was $59 \% .56 .6 \%$ of respondents were part-time workers, $14.3 \%$ of respondents as entrepreneurs and the remaining of $11.6 \%$ also worked part-time. $65.7 \%$ of respondents lived in parents' homes. $74.9 \%$ of respondents were Chinese. The majority of them were Buddhist (66.9\%) and Protestant Christians $(16.7 \%)$. The average respondent had been working for less than five years. $91.6 \%$ of respondents have income below IDR 5,000,000. 37.7\% of respondents learned financially from primary socialization agents (31.4\% from parents) and the rest from secondary agents (schools by 27.3\%). Regarding financial management, $66.8 \%$ of respondents preferred saving funds in banks.

\section{Analysis of Answers to Respondent Characteristics}

The financial self-efficacy variable got a variety of responses depending on ethnicity, income, and secondary socialization agents. Respondents from other ethnic groups and Minang Tribe gave a higher score than the Nias ethnic group and respondents who did not answer. Respondents with an income of more than IDR 10 million gave a higher score than those whose income was around IDR 5 to 10 million. Respondents who learned financially from print media scored higher than respondents who did not have secondary agents.

The financial attitude variable accepted different respondents' responses depending on marital status, ethnicity, and income. Unmarried respondents scored higher than those who were divorced. Respondents from other and Batak Tribe presented higher scores than Nias Tribe. Respondents whose income was over IDR 10 million gave a higher score than those whose income was IDR 5 to 10 million and respondents who did not answer.

The financial knowledge variable had different respondents' responses based on gender. Male respondents gave higher scores than women; especially on the indicator, "I understand how to minimize risk in investments."

Financial behavior variables, in general, did not obtain differences in respondent responses. However, on the indicator "I buy bonds, stocks, or mutual funds," respondents who liked to put funds in securities gave a higher score than those who put funds in digital assets. 
Respondents generally responded locus of control variables differently. However, the indicator "When I get what I want, usually because I work hard" received many different responses, especially based on gender, employment, and ethnicity. Female respondents gave a higher score than men. Respondents who had not gotten jobs gave a higher score than unemployment. Respondents from other and Batak Tribe gave higher scores than Nias Tribe and respondents who did not answer.

The financial well-being variable got different responses in terms of work, and the respondent's revenues. Respondents who had not worked provided a higher score than respondents who worked part-time. Respondents whose income was higher than IDR 5 to IDR 15 million gave a higher score than those whose income was above IDR 15 million and respondents who did not provide answers.

Table 2

Validity and Reliability Test Results

\begin{tabular}{ccc}
\hline Indicator & Pearson Correlation & Cronbach's Alpha \\
\hline FSE1 & $0.797 * * *$ & 0.803 \\
FSE2 & $0.645 * * *$ & \\
FSE3 & $0.790^{* * *}$ & \\
FSE4 & $0.777 * * *$ & \\
FSE5 & $0.739 * * *$ & 0.625 \\
FA1 & $0.674 * * *$ & \\
FA2 & $0.192 * * *$ & \\
FA3 & $0.718 * * *$ & \\
FA4 & $0.663 * * *$ & 0.803 \\
FA5 & $0.769 * * *$ & \\
FK1 & $0.710^{* * *}$ & \\
FK2 & $0.845 * * *$ & \\
FK3 & $0.835 * * *$ & 0.715 \\
FK4 & $0.646 * * *$ & \\
FK5 & $0.708 * * *$ & \\
FB1 & $0.746 * * *$ & \\
FB2 & $0.772 * * *$ & \\
FB3 & $0.792 * * *$ & \\
FB4 & $0.807 * * *$ & \\
FB5 & $0.246 * * *$ & \\
LC1 & $0.668 * * *$ & \\
LC2 & $0.748 * * *$ & \\
LC3 & $0.758^{* * *}$ & \\
LC4 & $0.773 * * *$ & \\
LC5 & $0.516 * * *$ & \\
FW1 & $0.730^{* * * *}$ & \\
FW2 & $0.734 * * *$ & \\
FW3 & $0.826 * * *$ & \\
FW4 & $0.783 * * *$ & \\
FW5 & $0.659 * * *$ & \\
& $* * *$ Significant at $1 \%$ & \\
\hline & & \\
\end{tabular}

Table 2 shows testing the validity of using Pearson correlation producing $1 \%$ significance for all indicators. For reliability testing with Cronbach's Alpha, the lowest value is 0.625 and meets the requirements above 0.6. The next stage of analysis is the classic assumption of multiple regression analysis.
Table 3

Test Results of Classical Assumptions and Multiple Linear Regressions

\begin{tabular}{cccccc}
\hline Variable & $B$ & $t$ & Sig. & VIF & Sig. 2 \\
\hline (Constant) & 0.789 & 2.729 & 0.007 & & \\
FSE & 0.145 & 2.149 & 0.033 & 1.466 & 0.385 \\
FA & 0.117 & 1.700 & 0.091 & 1.720 & 0.141 \\
FK & 0.097 & 1.769 & 0.078 & 1.158 & 0.095 \\
FB & 0.274 & 4.206 & 0.000 & 1.629 & 0.577 \\
LC & 0.102 & 1.519 & 0.130 & 1.540 & 0.304 \\
Adjusted & & & & & \\
$R$ Square & \multicolumn{2}{c}{0.302} & \multicolumn{2}{c}{ Sig.3 } & 0.067 \\
$F$ Test & 21.643 & \multicolumn{2}{c}{ Sig.4 } & 0.187 \\
$F$ Sig. & 0.000 & &
\end{tabular}

Explanation:

1. $\quad$ F Sig. $<0,05=$ Good Model (Linearity)

2. $\mathrm{VIF} \leq 5=$ Moderately correlated (Daoud, 2017)

3. Sig. $2=$ Sig. of Glejser Test $>0,05=$ No Heteroscedasticity (Nwakuya \&Nwabueze, 2018)

4. Sig. $3=$ Sig. of Shapiro-Wilk Test $>0,05=$ Normally Distributed Data (Razali \& Yap, 2011)

5. Sig. $4=$ Sig. of Runs Test $>0,05=$ No Autocorrelation (Uyanto, 2020)

Based on Table 3, the classic assumptions of multiple regressions such as normality, multicollinearity, autocorrelation, and heteroscedasticity meet the requirements. $F$ value of Sig. below 0.05 , the research model is good. The highest VIF value is 1.720 (still below 5), so there is no multicollinearity (Daoud, 2017). The lowest Sig. of Glejser Test value is 0.095 (above 0.05 ), so there is no heteroscedasticity (Nwakuya \& Nwabueze, 2018). Sig. of Shapiro-Wilk Test produces values above 0.05 . Hence, the distribution of residuals is classified as normal (Razali \& Yap, 2011). Sig. of Run Test is 0.187 (above 0.05), so there is no autocorrelation (Uyanto, 2020).

Adjusted $R$ Square (used if the independent variable is more than 2) explains how much influence the independent variable has on the dependent variable. All independent variables affect $30.2 \%$ (weak) on financial well-being while the rest is influenced by other factors. Based on these data, the regression model is as follows:

Financial Well-Being $=0.789+0,145$ Financial SelfEfficacy +0.117 Financial Attitude +0.097 Financial Knowledge + 0.274 Financial Behaviors + 0.102 Locus of Control $+e$

\section{Hypothesis Testing}

Testing using SPSS produces the effect of each variable. It also describes the research hypothesis testing.

Hypothesis 1: Financial self-efficacy has a significant positive effect on financial well-being (5\%); hypothesis 1 is accepted. Hypothesis 2: there is a positive 
and significant influence of financial attitude on financial well-being (10\%); hypothesis 2 is accepted. Hypothesis 3: there is a positive influence of financial knowledge on financial well-being (10\%). Hypothesis 3 is accepted. Hypothesis 4: financial behavior has a positive and significant influence on financial well-being (1\%); hypothesis 4 is accepted. On the other hand, Hypothesis 5: the positive influence of locus of control on financial well-being is not significant, so it is rejected.

\section{Discussion}

\section{Influence of Financial Self-Efficacy on Financial Well-Being}

The positive influence of financial self-efficacy on financial well-being is significant because financial wellbeing rises with increasing financial independence. This is in line with the study (Serido, Shim, \& Tang, 2013) and (Heo, Saboe-Wounded Head, Cho, \& Lee, 2018). When they are confident in their capacity to manage finances, they are satisfied with their financial situation. Someone who succeeds to find a way to achieve what they want with his maximum performance will be more confident in managing finances. How much effort should be extended in these efforts, how long to survive in the face of obstacles and failures, and whether the failure is motivating or discouraging to achieve financial well-being.

\section{Influence of Financial Attitude on Financial Well- Being}

Financial attitude positively and signifycantly influences financial well-being because generation $\mathrm{Z}$ has great enthusiasm for investing. Invest regularly is the key factor. The results are similar studies as done by Falahati and Sabri (2015), Sabri and Zakaria (2015), and Zulfiqar and Bilal (2016), but they conflict with done by Abdullah et al. (2019). By good financial management, they understand well the process of financial management. Abdullah et al. (2019) argued an individual with a positive attitude towards money such as retention, inadequacy, and effort/ability can help young workers manage their money wisely. Also Sabri and Zakaria (2015) emphasized the positive attitude towards money to help them be more careful in spending money. This is part of long-term thinking about planning for future financial needs. The ability to manage money is important so that money can be planned well. The ability to plan money or a budget is important because it will allow a person to make smart financial decisions and avoid spending more than they can get and help their financial well-being.

\section{Influence of Financial Knowledge on Financial Well- Being}

Financial knowledge influences financial wellbeing significantly and positively. The main cause is that generation $\mathrm{Z}$ pays attention to its financial well-being and wants to increase its financial knowledge for financial freedom. This conclusion is directly proportional to the study of Falahati and Sabri (2015) and Lee, Park, and Heo (2019). Generation Z understands financial concepts such as money management, investment, and budgeting. Therefore, they can minimize investment risk by learning from someone successful. Understanding of inflation also can help them to manage finances better in the future. A person with a high level of financial knowledge will have the ability to understand and analyze financial options, plan their financial future, and respond appropriately according to the various financial situations encountered.

\section{Influence of Financial Behavior on Financial Well- Being}

Moreover, financial behavior is proven to influence financial well-being positively and significantly because good habits produce good thinking. Delafrooz and Paim (2011a, 2011b), Mokhtar and Rahim (2017), Mokhtar and Rahim (2016), Sabri and Falahati (2003), Sabri et al. (2013), and Serido, Shim, and Tang (2013) agreed with this. Good financial management practices support financial well-being. Parents or teachers have a vital role by teaching the habit of saving money every month for future needs. After realizing the sufficient funds, someone can control their funds for business, consequently making them more prosperous. They also need to analyze their budget before making a large purchase. Practicing better financial behavior and worrying about financial planning are more likely to achieve a higher level of financial well-being.

\section{Influence of Locus of Control on Financial Well- Being}

On the other hand, locus of control does not influence the financial well-being. This is because generation $\mathrm{Z}$ prefers instant ways to achieve financial prosperity. This was also proven by research of Mokhtar and Rahim (2017). Mokhtar and Rahim (2016) had different opinions. From the descriptive side, overall there is no significant difference in the characteristics of 
respondents in the locus of control. Everyone must be responsible for his or her conditions. In fact, generation $\mathrm{Z}$ cannot do it due to many factors, such as the family's economic status, and those who are already working will deposit funds for the needs of their parents. Even in such conditions, they still must be able to save and invest carefully. They must adopt the best financial practices, such as budgeting, savings, financial planning, and paying bills on time, to improve financial well-being.

\section{Conclusion and Implication}

\section{Conclusions}

This study aims to observe the factors affecting the financial well-being of generation $\mathrm{Z}$. The results of the study conclude there is a significant influence of financial self-efficacy on financial well-being, significant influence of financial attitude on financial well-being, significant influence of financial knowledge on financial well-being, and significant influence of financial behavior on financial well-being. However, the locus of control does not influence financial well-being significantly. The effect of financial self-efficacy on financial wellbeing is significant because generation $\mathrm{Z}$ must expand its own efforts to achieve its financial goals. The influence of financial attitude on financial well-being is significant because the attitude of money management will cause someone to be careful in controlling money. Financial literacy is important to financial well-being because increasing financial literacy will help you reach your financial level. Locus of Control is insignificant for financial well-being because this generation is young and inexperienced and must support their parents while they want to get rich quickly.

\section{Implications}

The implication of this research is that generation $\mathrm{Z}$ must increase their independence and confidence to achieve what they want. It would be good to have financial atitude and investment behavior along with financial knowledge. They must also believe that only theirself can provide personal well-being.

The results also reveal the need for financial education for generation $\mathrm{Z}$ and others, especially the alpha generation. They need character education, more mature, and independent thinking models to deal with economic problems. Character education is more important because locus of control did not give significant effect. Positive thinking and habits, even the smallest chance, will make them more confident to bring out their best abilities.
The weakness of this study is the variable is limited to what is commonly used in human resource management research. Future research is expected to utilize a more diverse number of samples and interdisciplinary variables to strengthen hypotheses.

\section{References}

Abdullah, N., Sabri, M, F., \& Arif, A. M. M. (2019). The relationship between attitude towards money, financial literacy and debt management with young worker's financial well-being. Pertanika Journal of Social Sciences and Humanities, 27(1), 361378.

Ali, A., Rahman, M. S. A., \& Bakar, A. (2013). Financial literacy and satisfaction in Malaysia: A pilot study. International Journal of Trade, Economics and Finance, 4(5), 319-324. https://doi.org/10.7763/ IJTEF.2013.V4 .309

Ameliawati, M., \& Setiyani, R. (2018). The Influence of financial attitude, financial socialization, and financial experience to financial management behavior with financial literacy as the mediation variable. International Conference on Economics, Business and Economic Education 2018, KnE Social Sciences, 811-832. https://doi.org/10.18502/kss.v3i10. 3174

Arifin, A. Z. (2017). The influence of financial knowledge, control and income on individual financial behavior. European Research Studies Journal, XX(3A), 635-648.

------ (2018). Influence factors toward financial satisfaction with financial behavior as intervening variable on Jakarta area workforce. European Research Studies Journal, XXI(1), 90-103.

Bujang, M. A., Sa'at, N., \& Sidik, T. M. I. T. A. B. (2017). Determination of minimum sample size requirement for multiple linear regression and analysis of covariance based on experimental and non-experimental studies. Epidemiology Biostatistics and Public Health, 14(3), e12117-1-e121179. https://doi. org/10.2427/12117

Daoud, J. I. (2017). Multicollinearity and regression analysis. IOP Conf. Series: Journal of Physics: Conference Series, 949(012009), 1 -6. https://doi.o rg/10.1088/1742-6596/949/ 1/012009

Delafrooz, N., \& Paim, L. H. (2011a). Determinants of financial wellness among Malaysia workers. African Journal of Business Management, 5(24), 10092-10100. https://doi.org/10.5897/ajbm10.1267. (2011b). Determinants of saving behavior and financial problem among employees in Malaysia. Australian Journal of Basic and Applied Sciences, 5(7), 222-228. 
Faique, F. A., Ismail, S., Bakri, M. H., Idris, N. H., Yazid, Z. A., Daud, S., \& Taib, N. M. (2017). Testing the financial attitude as a mediator for the relationship between financial self-efficacy with financial behavior. Advanced Science Letters, 23(8), 8009-8012. https://doi.org/10.1166/asl.2017.9632.

Falahati, L., \& Sabri, M. F. (2015). An exploratory study of personal financial wellbeing determinants: Examining the moderating effect of gender. Asian Social Science, 11(4), 33-42. https://doi.org/10. 5539/ass.v11n4p3 3

Fitra, H., Rasyid, R., \& Susanti, Y. (2018). The influence of locus of control and financial knowledge to employee investing decision PT. Pertamina (Persero) Branch of Padang. In Proceedings of the First Padang International Conference on Economics Education, Economics, Business and Management, Accounting and Entrepreneurship (PICEEBA 2018) (Vol. 57, pp. 174-184). Atlantis Press. https://doi.org/10.2991/piceeba-18.2018.45

Heo, W., Saboe-Wounded Head, L., Cho, S. H., \& Lee, P. S. (2018). Association between personality and financial well-being: Strategies for more effective financial education, counseling and advising. Consumer Interests Annual, 64, 1-5. Retrieved from https://www.consumerinterests.org/assets/docs/ CIA/CIA2018/HeoCIA18.pdf

Herawati, N. T., Candiasa, I. M., Yadnyana, I. K., \& Suharsono, N. (2018). Factors that influence financial behavior among accounting students in Bali. International Journal of Business Administration, 9(3), 30-38. https://doi.org/10.5430/ijba.v9 $\mathrm{n} 3 \mathrm{p} 30$

Kumar, S., Watung, C., Eunike, J., \& Luinata, L. (2017). The Influence of financial literacy towards financial behavior and its implication on financial decisions: A survey of President University students in Cikarang - Bekasi. Firm Journal of Management Studies, 2(1), 169-179. Retrieved from http://e-journal.president.ac.id/presunivojs/index. php/FIRM-JOURNAL/article/view/158/87

Lee, J. M., Park, N., \& Heo, W. (2019). Importance of subjective financial knowledge and perceived credit score in payday loan use. International Journal of Financial Studies, 7(3), 1-21. https://doi.org/ 10.3390/ijfs7030 053

Lind, D. A., Marchal, W. G., \& Wathen, S. A. (2017). Statistical techniques in business \& economics. Seventeenth Edition. New York: McGraw-Hill Education.

Lown, J. M. (2011). Development and validation of a financial self-efficacy scale. Journal of Financial Counseling and Planning, 22(2), 54-63.
Mien, N. T. N., \& Thao, T. P. (2015). Factors affecting personal financial management behaviors: Evidence from Vietnam. In Proceedings of the Second Asia-Pasific Conference on Global Business, Economics, Finance and Social Sciences (AP15Vietnam Conference) (pp. 1-16). Danang-Vietnam. https://doi.org/10.1161/01.HYP.0000200705. 61571. 95

Mokhtar, N., \& Rahim, H. A. (2016). Determinants of Employee perception on financial well-being in Putra Jaya. Malaysian Journal of Consumer and Family Economics, 19, 27 -51.

(2017). Determinants of financial well-being among public employees in Putrajaya, Malaysia. Pertanika Journal of Social Sciences and Humanities, 25(3), 1241-1260.

Nwakuya, M. T., \& Nwabueze, J. C. (2018). Application of box-cox transformation as a corrective measure to heteroscedasticity using an economic data. American Journal of Mathematics and Statistics, 8(1), 8-12. https://doi.org/10.5923/j.ajms.20180 801.02

Pinjisakikool, T. (2017). The effect of personality traits on households' financial literacy. Citizenship, Social and Economics Education, 16(1), 39-51. https://doi.org/10.1177/20471 73417690005

Potrich, A. C. G., Vieira, K. M., \& Kirch, G. (2015). Determinants of financial literacy: Analysis of the influence of socioeconomic and demographic variables. Revista Contabilidade \& Finanças, 26(69), 362-377. https ://doi.org/10.1590/1808$057 \times 201501040$

Potrich, A. C. G., Vieira, K. M., \& Mendes-Da-Silva, W. (2016). Development of a financial literacy model for university students. Management Research Review, 39(3), 356-376. https://doi.org/10.1108/ MMR-06-2014 -0143

Razali, N. M., \& Yap, B. W. (2011). Power comparisons of Shapiro-Wilk, Kolmogorov-Smirnov, Lilliefors, and Anderson-Darling Tests. Journal of Statistical Modeling and Analysis, 2(1), 21-33.

Sabri, M. F., \& Falahati, L. (2003). Predictors of financial well-being among Malaysian employees: Examining the mediate effect of financial stress. Journal of Emerging Economies and Islamic Research, 1(3), 1-16. Retrieved from http://www.jeeir.com/index.ph p/jeeir/article/view/74

Sabri, M. F., Paim, L., Falahati, L., \& Masud, J. (2013). Determinants of employees' financial well-being: The moderation effect of work sectors. Malaysian Journal of Consumer and Family Economics, 16, 91-106. 
Sabri, M. F., \& Zakaria, N. F. (2015). The influence of financial literacy, money attitude, financial strain and financial capability on young employees' financial well-being. Pertanika Journal of Social Sciences and Humanities, 23(4), 827-848.

Schwarzer, R., \& Jerusalem, M. (1995). General selfefficacy scale. Causal and Control Beliefs, 35-37.

Sekaran, U., \& Bougie, R. (2016). Research method for business a skill-building approach. Seventh Edition. Chichester: John Wiley \& Sons. https://doi. org/10.1007/978-94-007-0 753-5_102084

Serido, J., Shim, S., \& Tang, C. (2013). A developmental model of financial capability: A framework for promoting a successful transition to adulthood. International Journal of Behavioral Development, 37(4), 287-297. https://doi.org/10.1177/016502 5413479476.
Susan, M. (2018). Financial behavior and problems among college student in indonesia: The role of financial knowledge. International Journal of Engineering \& Technology, 7(3.25), 133-137. http://dx.doi.org/10.1441 9/ijet.v7i3.25.17531

Taherdoost, H. (2016). Validity and reliability of the research instrument: How to test the validation of a questionnaire/survey in a research. International Journal of Academic Research in Management (IJARM), 5(3), 28-36. https://doi.org/10.2139/ ssrn.3205040

Uyanto, S. S. (2020). Power comparisons of five most commonly used autocorrelation tests. Pakistan Journal of Statistics and Operation Research, 16(1), 119-130. https://doi.org/10.18187/pjsor. v16i1.2691

Zulfiqar, M., \& Bilal, M. (2016). Financial wellbeing is the goal of financial literacy. Research Journal of Finance and Accounting, 7(11), 94-103. 